\title{
Social responses to climate change in Iron Age north-east Thailand: new archaeobotanical evidence
}
Cristina C. Castillo ${ }^{1,}{ }^{*}$, Charles F.W. Higham ${ }^{2}$, Katie Miller ${ }^{1}$, Nigel Chang ${ }^{3}$, Katerina Douka ${ }^{4,5}$, Thomas F.G. Higham ${ }^{4} \&$ Dorian Q Fuller ${ }^{1}$

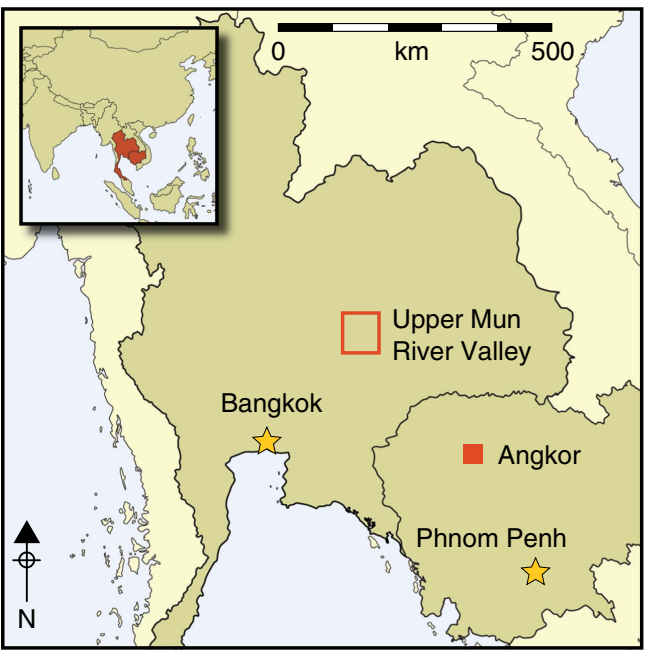

New evidence from archaeological investigations in north-east Thailand shows a transition in rice farming towards wetland cultivation that would have facilitated greater yields and surpluses. This evidence, combined with new dates and palaeoclimatic data, suggests that this transition took place in the Iron Age, at a time of increasingly arid climate, and when a number of broader societal changes become apparent in the archaeological record. For the first time, it is possible to relate changes in subsistence economy to shifts in regional climate and water-management strategies, and to the emergence of state societies in Southeast Asia.

Keywords: Thailand, Southeast Asia, Iron Age, rice farming, weed flora, agricultural intensification, archaeobotany

\section{Introduction}

The civilisation of Angkor and its Southeast Asian contemporaries adapted to an unstable monsoon climate, with intense precipitation from April to October, and virtually no rainfall

University College London, Institute of Archaeology, 31-34 Gordon Square, London WC1H OPY, UK

University of Otago, Anthropology and Archaeology, P.O. BOX 56, Dunedin 9016, New Zealand

3 James Cook University, College of Arts, Society and Education, Townsville QLD 4811, Australia

4 Oxford Radiocarbon Accelerator Unit, Research Laboratory for Archaeology and the History of Art, Dyson Perrins Building, South Parks Road, University of Oxford, Oxford OX1 3QY, UK

5 Max Planck Institute for the Science of Human History, Department of Archaeology, Kablaische Strasse 10, D-07745 Jena, Germany

* Author for correspondence (Email: cristina.castillo@ucl.ac.uk)

(C) Antiquity Publications Ltd, 2018. This is an Open Access article, distributed under the terms of the Creative Commons Attribution licence (http://creativecommons.org/licenses/by/4.0/), which permits unrestricted re-use, distribution and reproduction in any medium, provided the original work is properly cited. 
for the rest of the year (Wohlfarth et al. 2016). This paper summarises the most recent evidence for historical climate change in this region and the consequences for rice production and social organisation. The identification of systems of water management for successful rice production was one of the principal results of recent research on the early states of Chenla (c. AD 550-800) and Angkor (c. 800-1430) in Cambodia (Fletcher et al. 2008; Hawken 2011). Without a rice surplus, these states could not have formed and maintained their hegemony. This requirement focuses attention on the nature of rice cultivation during the preceding prehistoric period, with particular reference to the origins of water management and the early intensification of rice production.

Ban Non Wat (BNW) is one of hundreds of prehistoric Iron Age settlements in the Mun River Valley of north-east Thailand (Figure 1A; Scott \& O'Reilly 2015). Excavations (20012011) have identified a cultural sequence divided into 12 phases: one possible huntergatherer (1750 BC-based on dates from flexed burials in the same layer as the early Neolithic material), two Neolithic (1750-1050 BC), six Bronze Age (1050-450 BC) and three Iron Age (450 BC-AD 500) (Higham \& Higham 2009; Higham \& Kijngam 2012). Here we report on the results of flotation to recover plant remains from a trench, N96, in conjunction with related botanical information from two nearby moated sites, Noen U-Loke (NUL) and Non Ban Jak (NBJ). NUL was occupied throughout the Iron Age (450 BC-AD 500), and is particularly relevant for its evidence of a sharp rise in the wealth and ritual investment in burials during the third of its four mortuary phases (AD 300-400), when the dead were interred in graves filled with rice (Higham \& Talbot 2007). NBJ was occupied during Iron Age 4, and has provided unique evidence for residential burials, the impact of reservoir construction on human health, and well-preserved plant remains (Figure 1). Preliminary archaeobotanical results from NBJ have been published by Higham et al. (2014).

Broadly, rice-cultivation systems can be classified as dryland or wetland (Fuller et al. 2011; Weisskopf et al. 2015). The former relies on rainfall, while wetland rice cultivation employs embankments to retain rainwater, which may be supplemented with water from reservoirs when the monsoon falters. Wetland rice agriculture, particularly when combined with ploughing, is the more labour-intensive and productive of the two systems (Fuller et al. 2011). Moreover, the generation of surplus through ownership of fixed fields and increased production resulting from water control become stimuli for the rise of social elites (Higham 2014; O'Reilly 2014), and central to the economies of historical Southeast Asian states (e.g. Stargardt 1986; Bray 1994; Scott 2009).

Now that the prehistoric cultural and chronological sequence in Southeast Asia is becoming clearer, it is possible to identify economic changes and their implications (Higham et al. 2015). This situation has been made all the more timely by new information on climate change obtained from lake cores and tree rings. The combination of high-resolution dating of changes in the archaeobotanical record, in the cultural sequence and in the strength of the monsoon presents the first opportunity to trace and explain how states formed and declined (Buckley et al. 2010). Below, we examine the drivers behind the social and economic changes in the context of increased aridity during the Late Iron Age.

\section{Defining rice cultivation systems through archaeobotany}

Archaeobotanical weed flora provide a proxy for the ecology of ancient fields and the identification of prehistoric rice-cultivation systems (e.g. Fuller \& Qin 2009; Castillo 2011;

(C) Antiquity Publications Ltd, 2018 
Cristina C. Castillo et al.
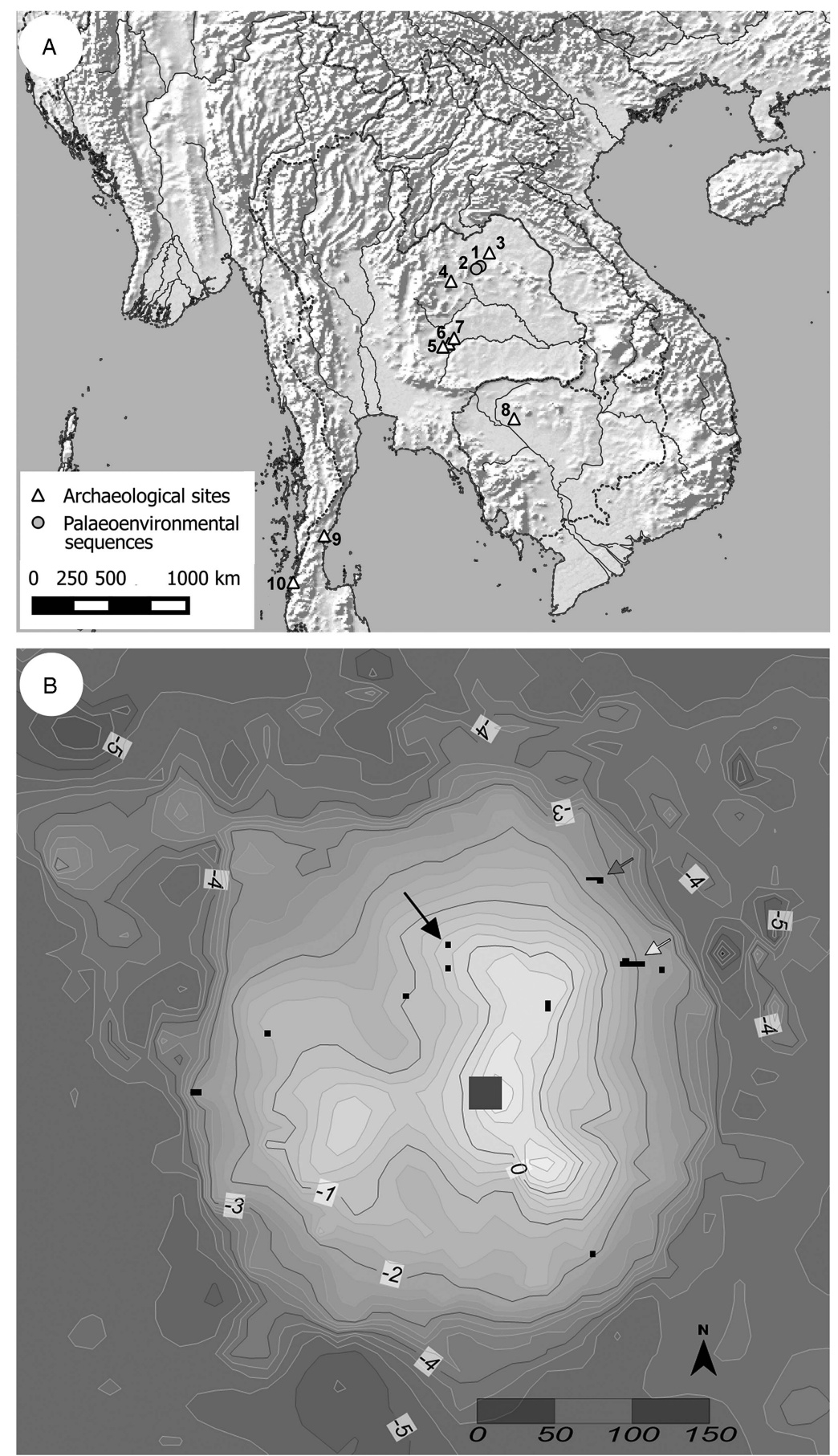

Figure 1. A) The location of the sites mentioned in the text: 1) Lake Kumphawapi; 2) Lake Pa Kho; 3) Ban Chiang; 4) Non Nok Tha; 5) Non Ban Jak (NBJ); 6) Noen U-Loke (NUL); 7) Ban Non Wat (BNW); 8) Angkor; 9) Khao Sam Kaeo; 10) Phu Khao Thong. B) Map showing the location of trenches excavated at BNW N96 (black arrow), K500 (grey arrow) and V200 (white arrow), contours in metres below the site datum.

(C) Antiquity Publications Ltd, 2018 
Weisskopf et al. 2015). Previous studies of weed flora at Southeast Asian sites show evidence of dry cereal cultivation such as that from the Late Bronze Age in central Thailand (Weber et al. 2010) and Iron Age Khao Sam Kaeo and Phu Khao Thong on the Thai-Malay peninsula (Figure 1; Castillo et al. 2016a). Rice field weeds and pulses at Khao Sam Kaeo are predominantly dryland species. The first evidence of a wetland rice-cultivation system in Mainland Southeast Asia comes from NBJ, located $11 \mathrm{~km}$ west of BNW, dating to the first half of the first millennium AD (Higham et al. 2014). Rice remains are abundant at NBJ, and the corresponding weed flora predominantly comprises plants that grow in water (hydrophytes).

The study of the macroremains assemblage from N96 at BNW is an advance on previous archaeobotanical studies because it has a continuous chronological sequence spanning the Bronze and Iron Ages that includes both rice and weed flora (Miller 2014). It provides the first example in Mainland Southeast Asia where a change from one cultivation system to another has been observed archaeologically in a single assemblage. Combined with samples from nearby sites, it provides a regional sequence that addresses the poorly understood shift from dry, rain-fed rice cultivation to more intensive wet rice systems (Fuller et al. 2011; Castillo et al. 2016a). This transition is of vital significance. Unlike dryland cultivation, which is dependent on unreliable rains, the predictability of rice harvests grown from bunded, ploughed and irrigated fields can sustain communities growing in both population and social complexity, although the maintenance of the system also requires greater social organisation.

\section{Methods}

The first rice and millet farmers reached Southeast Asia from southern China about 4000 years ago. This movement has been identified on the Khorat Plateau of north-east Thailand at BNW, Ban Chiang and Non Nok Tha from about 1700-1500 BC (Higham et al. 2015). Neolithic occupation at BNW ends in the eleventh century BC with the first copper-based artefacts found in burials of the earliest phase of the Bronze Age. Five further Bronze Age phases ensued, ending in the fifth century BC with the beginning of the Iron Age. At NUL, four Iron Age mortuary phases have been identified (Figure 2).

Four layers from N96 at BNW were analysed to provide a chronological sequence of seed assemblages (Table $S 1$ in the online supplementary material (OSM)). We obtained 14 direct AMS radiocarbon dates on the seeds, and interpreted them with stratigraphically informed Bayesian modelling (Figure 3; Tables S2-3). From these, two transitions in the climatic history of the site and associated human responses can be dated. The first is a gradual increase in aridity between $c .100 \mathrm{BC}$ and $\mathrm{AD} 100$. The second marks a more pronounced dry period in the Late Iron Age that coincided with the construction of the moats at NUL and NBJ, and with reservoirs at other key sites.

AMS radiocarbon dating was carried out at the Oxford Radiocarbon Accelerator Unit (ORAU). Four samples failed to produce results due to low yields after chemical pretreatment, so in the majority of cases, a variation on the routine method was used, and a less robust pre-treatment method was applied (ORAU code 'RR'; see Brock et al. 2010). This comprised a demineralisation with $1 \mathrm{M} \mathrm{HCl}(1 \mathrm{hr})$, a 15 -minute ultrasonication in fresh $1 \mathrm{M}$

(C) Antiquity Publications Ltd, 2018 


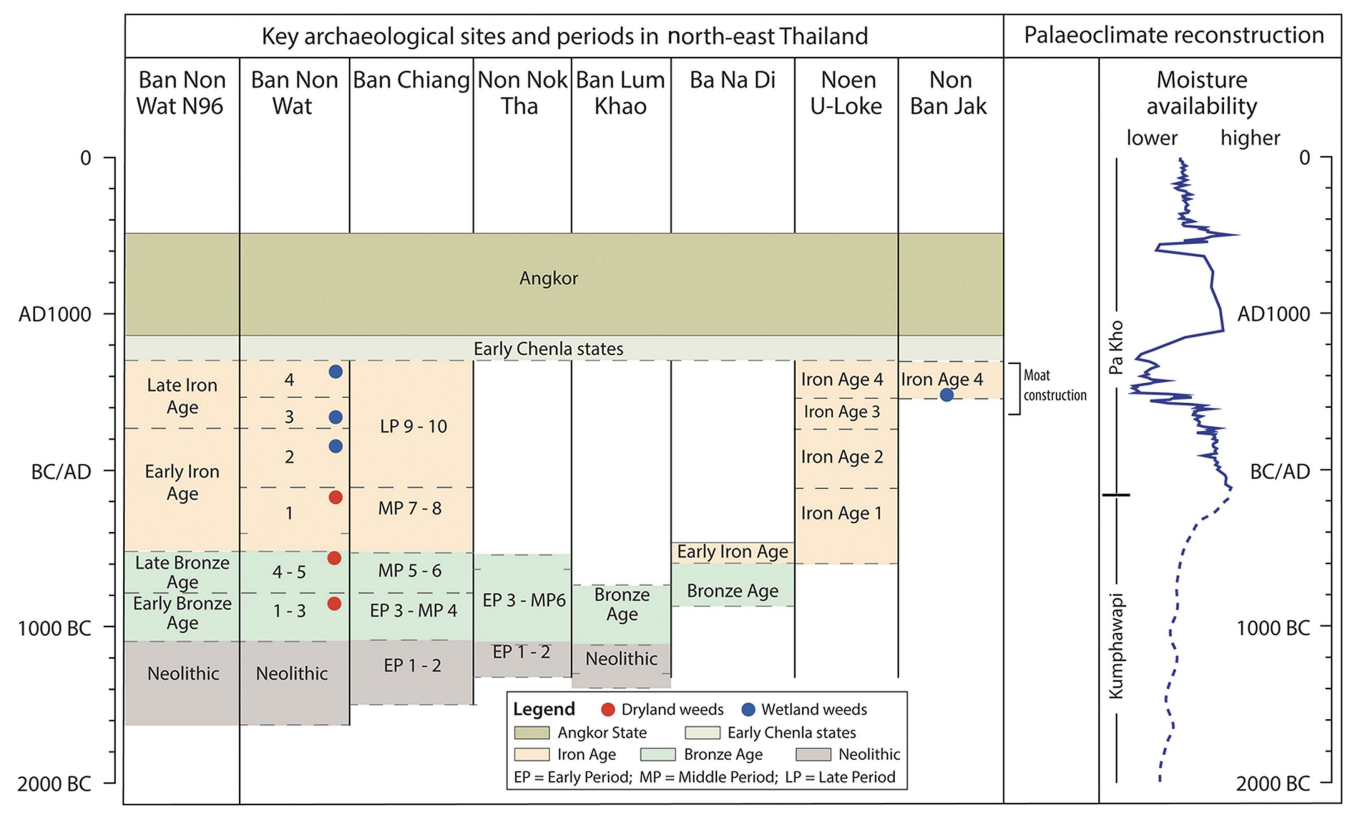

Figure 2. The archaeological sequences in the key sites, together with the reconstruction of the palaeoclimate, after Wohlfarth et al. (2016).

$\mathrm{HCl}$, rinsing in ultrapure water (4 times) before a final ultrasonication, again in fresh ultrapure water for 5 minutes ( $\times 6$ or until the water remained clear). The samples were then acidified for a further 5 minutes in $1 \mathrm{M} \mathrm{HCl}$ and rinsed twice with ultrapure water. Some samples (larger or less fragile seeds) were dated using the routine ' $Z R$ ' method, which includes a base wash designed to mobilise humates (Brock et al. 2010). Following pretreatment, samples were then dried and weighed in a pre-cleaned tin capsule, and combusted in a CF-IRMS system, consisting of a CHN elemental analyser (Carlo-Erba NA 2000) coupled to a gas-source isotope ratio mass spectrometer (Sercon 20/20). Purified $\mathrm{CO}_{2}$ from the combustion was converted to graphite using established protocols (Dee \& Bronk Ramsey 2000) and AMS dated in the Oxford HVEE accelerator mass spectrometer. Fourteen samples were dated (Table S3). The results were analysed using a Bayesian statistical modelling approach in OxCal 4.2 (Bronk Ramsey 2009). The results closely match those previously obtained for BNW from charcoal and freshwater bivalve shells (Higham \& Higham 2009), as summarised in Figure 2.

The 2011 field season at BNW involved excavation of a $4 \times 4 \mathrm{~m}$ trench (N96) that spanned Bronze and Iron Age occupations (Figure 1B). Macroremains were recovered from 19 contexts belonging to layers 3-6. The bucket wash-over flotation method with $250 \mu \mathrm{m}$ mesh bags was used to collect the botanical macroremains from a total of 292 litres of cultural deposits (Table 1). All 19 samples were subjected to a security assessment by quantifying uncharred/intrusive seeds and modern roots (Figure 4; Miller 2014). Our direct dating of macroremains (above) confirms the stratigraphic integrity of N96 (Figure 4), allowing us to use this sequence to track ecological changes in assemblage composition.

(C) Antiquity Publications Ltd, 2018 


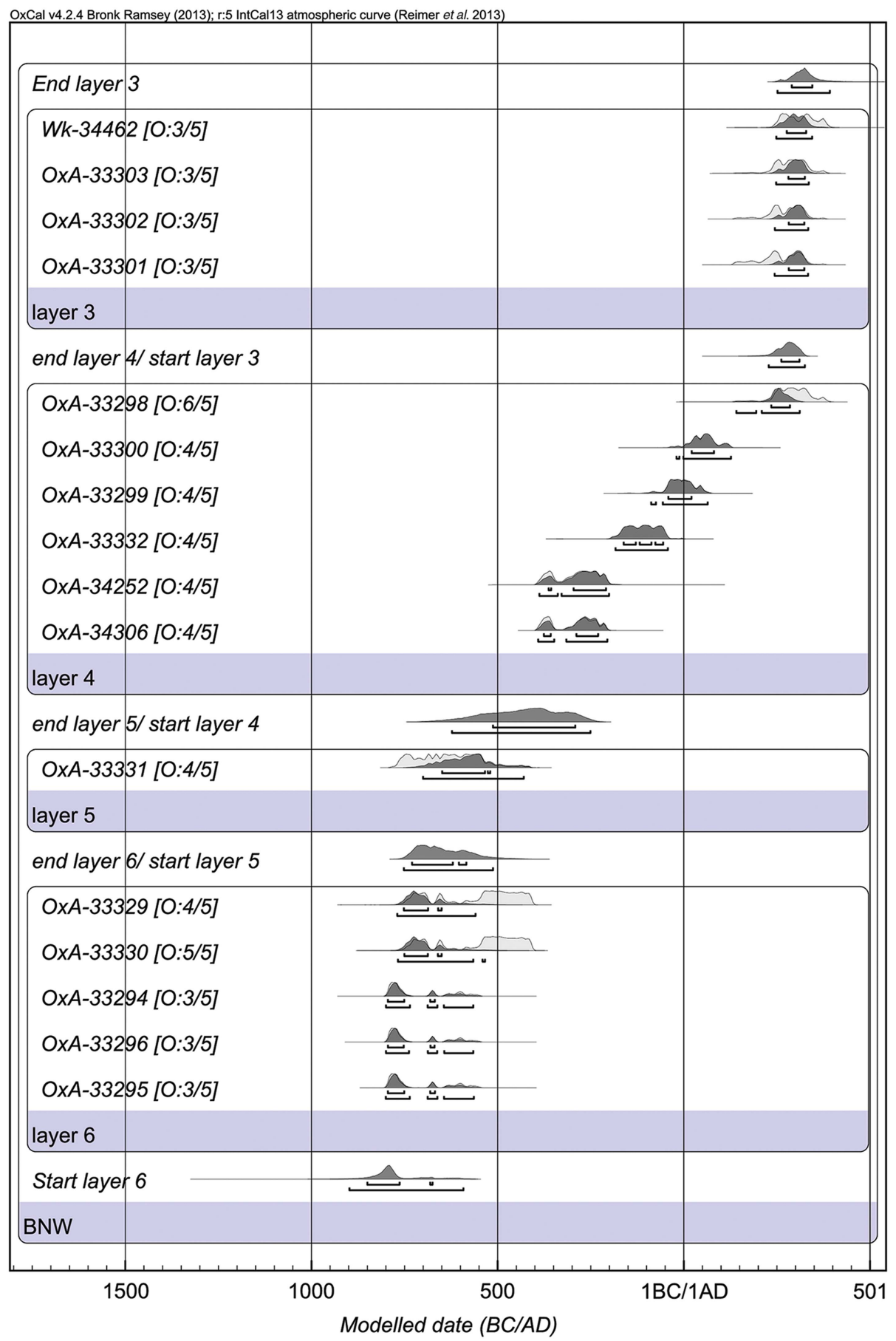

Figure 3. Bayesian model of AMS results excavated from square N96 at Ban Non Wat. (OxCal v4.0.5 Bronk Ramsey (2009); IntCal13 atmospheric curve (Reimer et al. 2013)). 


\section{Results: the macrobotanical remains}

Rice (Oryza sativa) was present in all layers except layer 6.7, which contained very few plant remains. All rice parts were charred, including grains, spikelet bases, husks and husk impressions (Figure 5). In all phases (layers 3-6), rice spikelet bases were predominantly of the domesticated type. This is expected for Bronze and Iron Age sites in Thailand as domesticated rice was already the main cultivar. The predominance of rice spikelet bases in many samples (Figure 5) is indicative of routine de-husking on site, whereas samples with a higher proportion of grains are suggestive of loss during food preparations including cooking.

Archaeogenetic and morphometric studies from other Bronze and Iron Age contexts at BNW and NUL indicate japonica-type grains (Figure 6; Castillo et al. 2016b). The morphometric analysis of rice grains from the Late Iron Age assemblage from N96 at $\mathrm{BNW}$, however, contains a significantly higher proportion of elongated rice grains, suggesting the presence of the subspecies indica (Figure 6), much like early historic assemblages from India (Castillo et al. 2016b). This suggests that the introduction of new rice varieties had begun by this time.

Rice dominates the macrobotanical assemblage, suggesting that it was a staple cereal and was probably monocropped. There is limited evidence for other plant foods being consumed (Table S4). Mesocarp (fruit flesh) and parenchyma (plant storage tissue) fragments are present in all four phases, and although not identifiable to species, they suggest the consumption of fruits, nuts and possibly tubers. Despite the consumption of foxtail millet (Setaria italica) elsewhere in prehistoric Thailand (Weber et al. 2010; Castillo et al. 2016a, 2017; Castillo 2017), no cultivated millets were identified at BNW.

\section{The regional sequence}

The results from BNW (including N96 and two other trenches K500 and V200), along with those from Late Iron Age NBJ, indicate a shift from dry to wet rice cultivation. Dryland weeds dominate the Early and Late Bronze Age contexts (Figures 7-8A). In the Early Iron Age, the proportion of dryland weeds decreases considerably, and weed types of an indeterminate (wet/dry) ecology are noted. In the Late Iron Age (layer 3 in BNW N96), wetland weeds dominate.

The dryland Acmella paniculata and wetland Diplacrum caricinum are the two main weed species represented in N96 (Figures 8B-9; Miller 2014). A. paniculata is associated with rice cultivation, including shifting agricultural systems in Thailand (Smitinand 1986; Moody 1989). It has been associated with dryland rice cultivation at Khao Sam Kaeo (fourth to first centuries $\mathrm{BC}$ ) and Phu Khao Thong (third BC to the early centuries $\mathrm{AD}$ ), which are contemporaneous with the Early Iron Age occupation of BNW (Castillo 2013). The presence of $A$. paniculata together with other dryland weeds indicates a relatively dryland cultivation system in N96. On the other hand, D. caricinum is an amphibious hydrophyte (emergent anchored aquatic plant) and is found in marshy and freshwater habitats (Raja et al. 2015). Furthermore, D. caricinum is associated with wet rice-fields in Thailand (Simpson \& Inglis 2001). In contrast, the main weed at NBJ is the hydrophyllic green algae Chara zeylanica (Higham et al. 2014). C. zeylanica, also known as green musk chara, occurs in shallow and (C) Antiquity Publications Ltd, 2018 
Table 1. Botanical macroremains from Ban Non Wat trench N96. NSP refers to number of specimens, NISP to number of identified specimens.

Number of samples floated

Average volume of soil floated (l)

Number of samples sorted

NSP

NISP*

Plant parts per litre MEAN

Plant parts per litre MIN

Plant parts per litre MAX

Number of taxa MODE

Number of taxa MIN

Number of taxa MAX

${ }^{*}$ Does not include modern plant parts and termite frass.

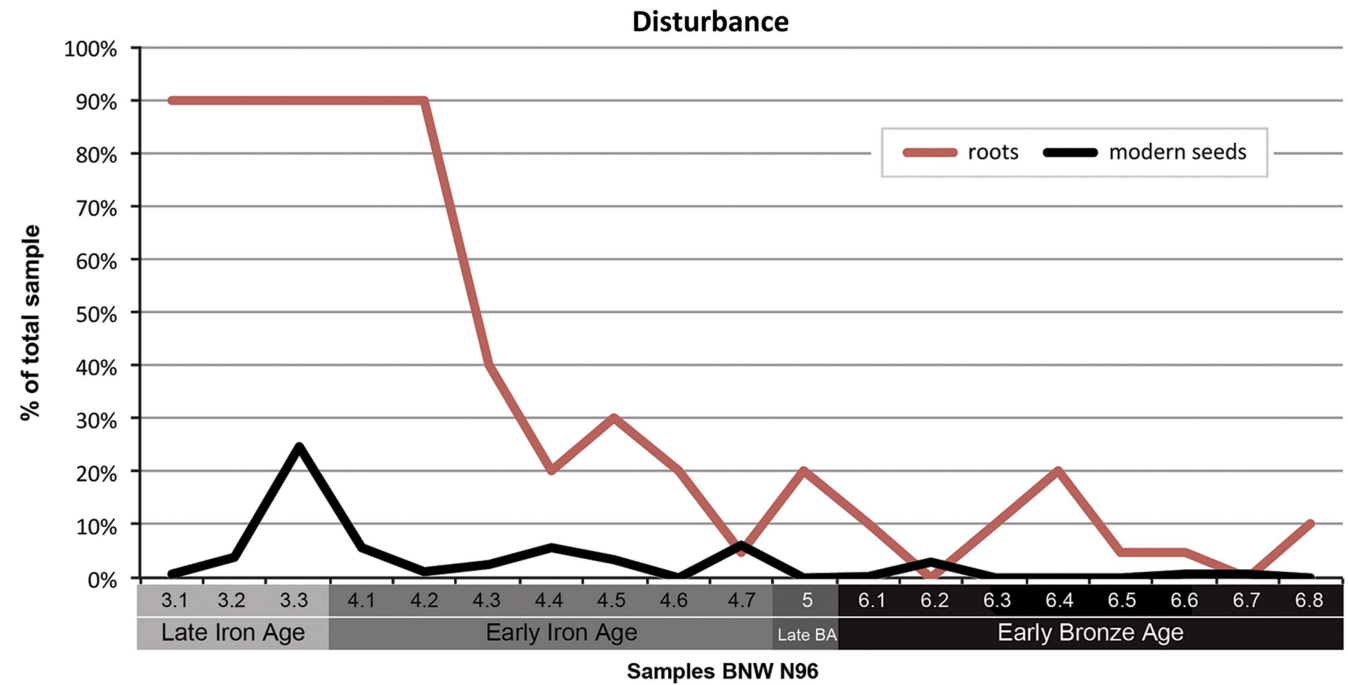

Figure 4. Graph plotting the estimated percentages of roots and modern specimens identified in samples from BNW N96.

deep water, infesting ponds, irrigated rice fields and irrigation channels (Piepho 1993; Pandey et al. 2005).

In the regional sequence (Figure 8A), the greatest proportion of dryland weeds, including A. paniculata, is found in the Late Bronze Age. There is an increase in the proportion of wetland weeds in the Iron Age contexts. Similarly, at N96, the highest proportion of A. paniculata occurs in the Bronze Age (Figure 7). We begin to see a shift towards wetland weeds in the middle of the Early Iron Age, although the dryland weed $A$. paniculata persists, albeit in decreasing quantities. Furthermore, the Early Iron Age shows the highest number of weed taxa overall, which may imply that a mixed rice cultivation system was used, especially during the first part of the Early Iron Age when farmers were beginning to develop wetland 


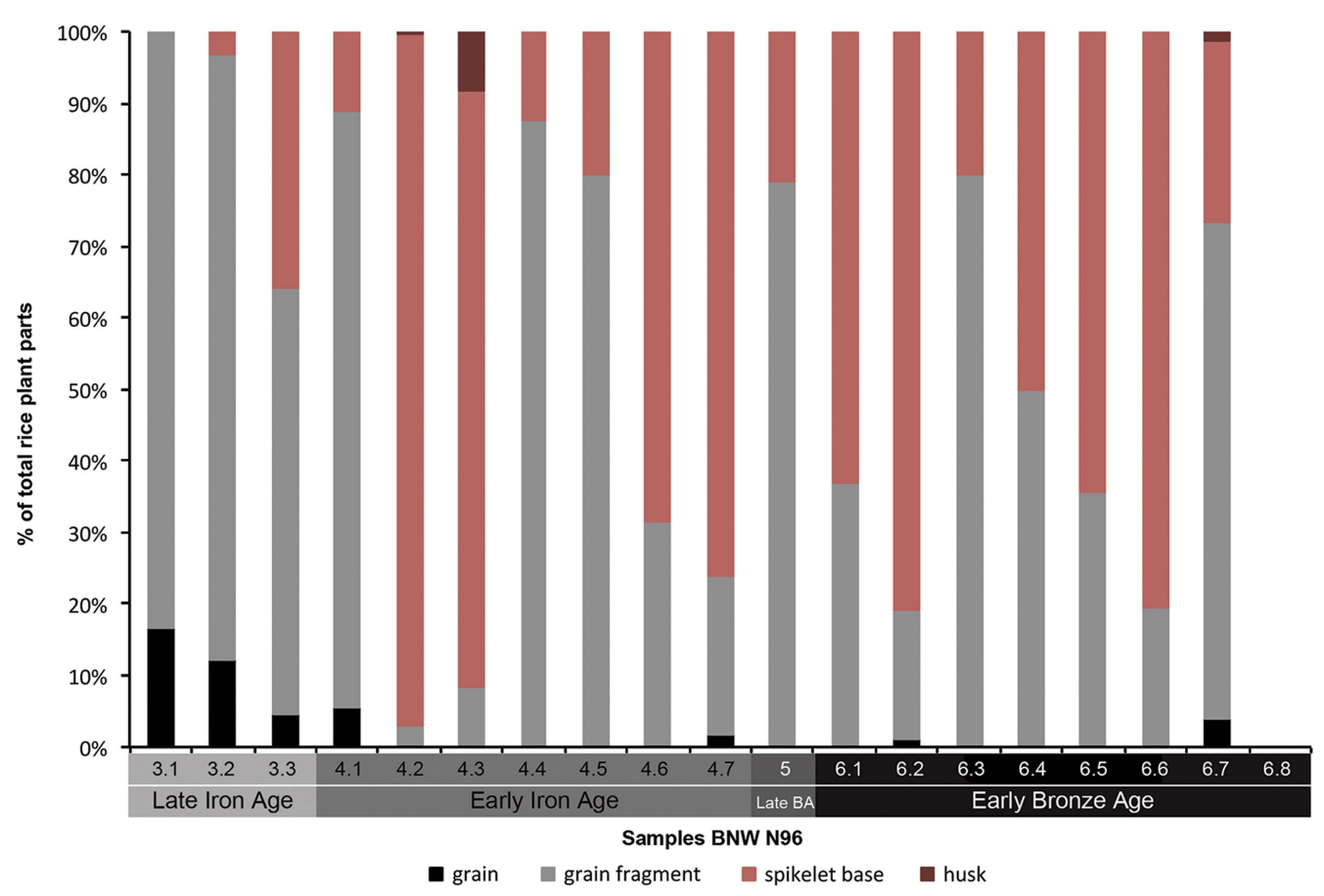

Figure 5. Recovered rice plant parts at BNW N96 by sample.

rice agriculture. A mixed rice cultivation system would allow for an improved level of food security by cultivating some fields under a wetland system, and others under a dryland system. This combination would provide some protection against crop failures in the event of unexpectedly low rainfall. The transition to wetland cultivation was seemingly under way during the Early Iron Age, but only in the Late Iron Age (AD 250-400) do wetland weeds come to dominate the regional sequence.

Our analysis suggests that wetland rice cultivation was practised at BNW from the Early Iron Age (in the first millennium AD) and almost exclusively in the Late Iron Age. Yet there are traces of dryland weeds at BNW that may imply some fields were still dry farmed alongside irrigated fields in the Early Iron Age. On the other hand, at NBJ, which was occupied only during the Late Iron Age, it appears to have been fully engaged in systems of wetland cultivation. A. paniculata, the most prominent dryland weed consistently found at Mainland Southeast Asian sites that practise dryland cultivation, was absent from all 23 of the samples analysed from the site, with green algae the dominant weed. Samples from NBJ extend into a later period than those from BNW, meaning that wetland cultivation may have been practised for several centuries, by which time dryland farming systems had been abandoned. NBJ probably corresponds to a later stage of more intensive wetland agriculture that started in the region around the time of the Early Iron Age, and which progressively became the dominant agricultural regime in the Mun River Valley by the Late Iron Age, producing higher rice yields and greater surpluses as a result. 


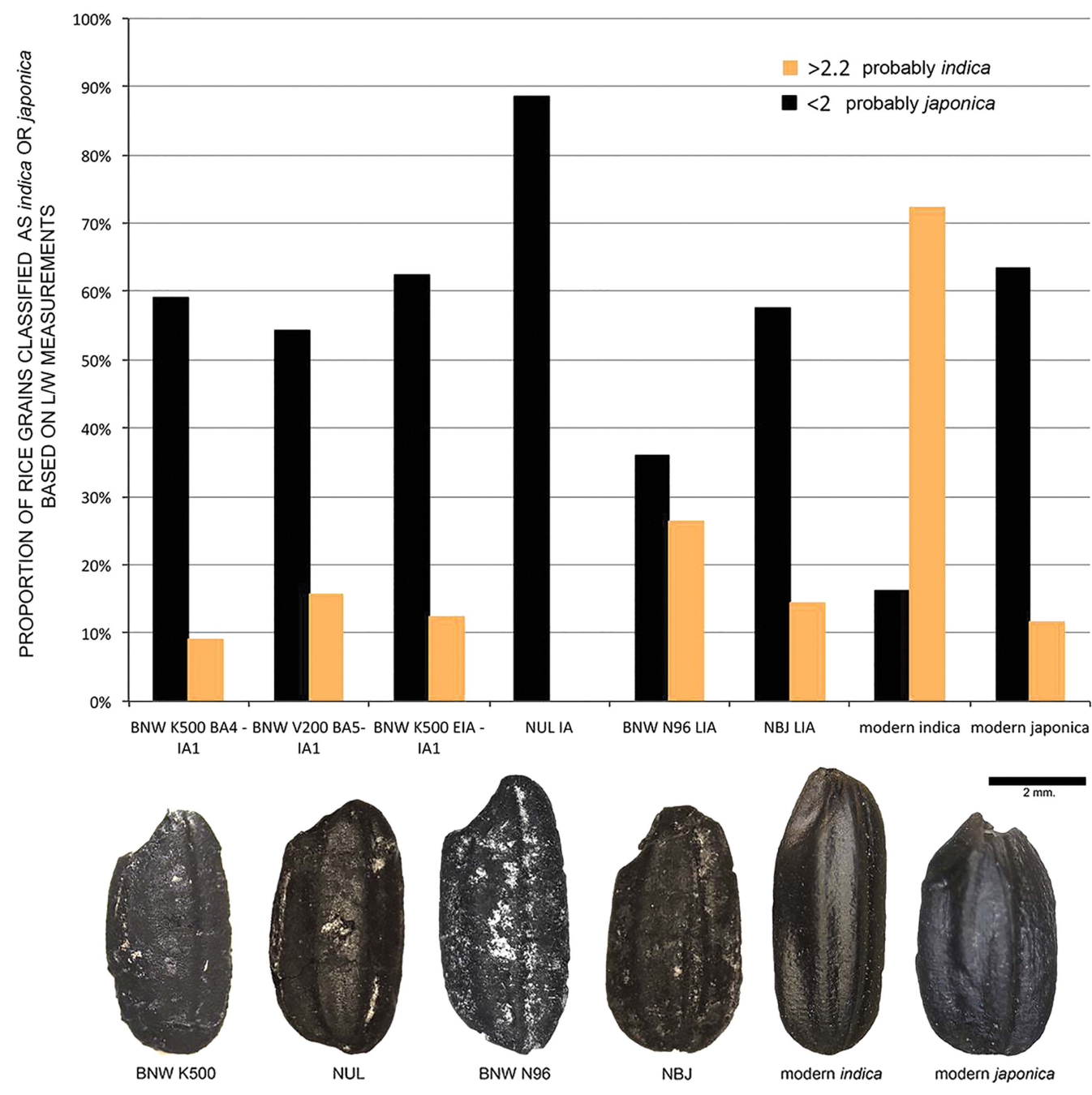

Figure 6. Proportions of archaeological (BNW, NUL and NBJ) and modern rice grains classified as indica or japonica according to length/width ratio. Ratios $<2$ are probably japonica, whereas those $>2.2$ are probably indica. Charred specimens are shown below; details on the morphometric analysis can be found in Castillo et al. (2016b).

\section{Discussion}

Changing rice cultivation systems in relation to climate, environment and social conditions

Prehistoric settlements in the upper Mun Valley were established along well-watered floodplains. There was a profound change with the transition to the Late Iron Age, around the end of the third century and beginning of the fourth century $\mathrm{AD}$, involving the construction of banks that encircled the settlements to create broad moats. At NUL, five such moats/reservoirs have a combined breadth of $200 \mathrm{~m}$. The shift in the rice cultivation system from dryland to wetland began during the Early Iron Age (at the beginning of the first century AD, corresponding to Early Iron Age layer 4.5 at BNW N96, see Figures $2 \& 7$ ).

(C) Antiquity Publications Ltd, 2018 


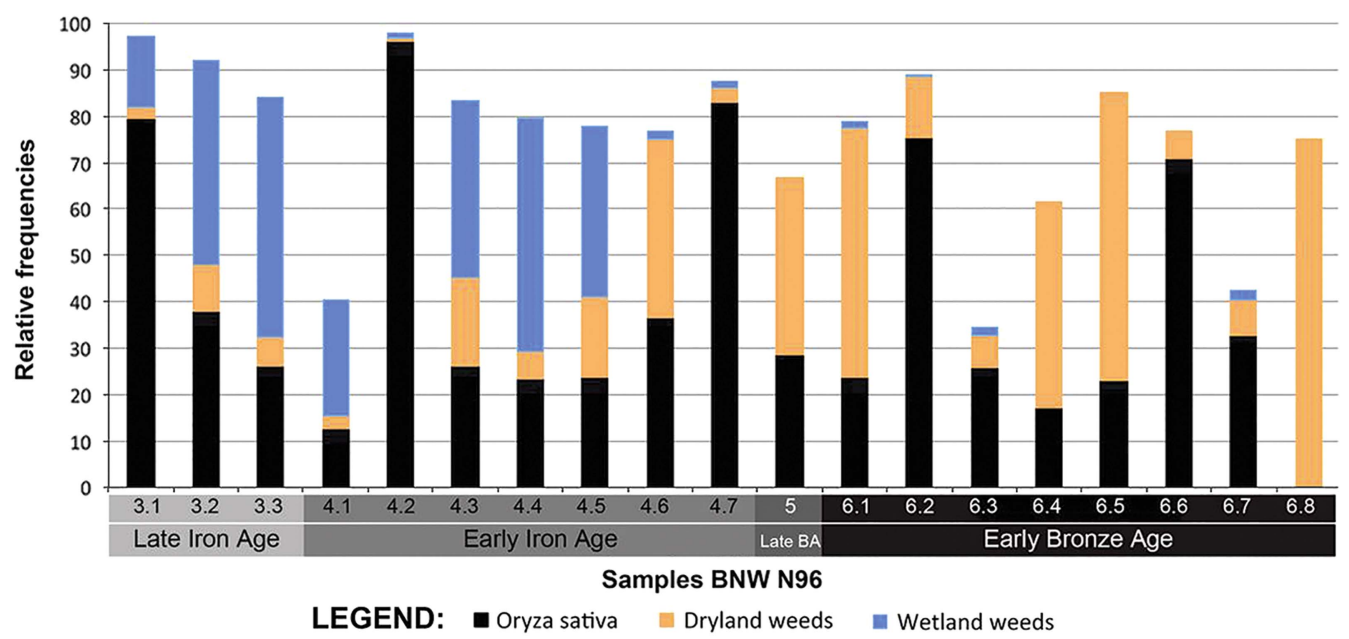

Figure 7. Relative frequencies of rice, dryland and wetland weeds from BNW N96. Relative frequency was calculated as the number of times a taxa occurred within a sample divided by the total number of specimens recovered from the sample. Relative frequency monitors the 'magnitudes' of past accidents of preservation (Sullivan 1987: 145). Proportions of taxa calculated using this method are dependent on the proportions of all the other taxa represented. Relative frequency does not account for spatial variation in the quantity of specific taxa recovered as samples are combined when proportions are calculated. Therefore, a single sample containing a large quantity of specific taxa can bias the representation of taxa across a site.

New research at Lakes Kumphawapi and Pha Ko has identified a decline in the strength of the monsoon starting in the first millennium $\mathrm{AD}$, leading to a sharp reduction in rainfall in the fifth century AD (Wohlfarth et al. 2016; Figure 2).

Could the development of wetland rice agriculture during the Iron Age represent an adaptation to a drier climate? The transition from dry to wet rice indicators in the weed flora took place sometime in the Early Iron Age, between $400 \mathrm{BC}$ and AD 200, and more specifically after the Early Iron Age layer 4.6 that ends $c .55$ BC. It is at this point that we begin to see a gradual decline in the rain-bearing capacity of the monsoon, although still wetter than the very dry conditions of the mid first millennium AD. This may indicate that the initial transition towards wet rice production was driven by socio-economic motives at a time of changing climatic conditions. Increased demand for surplus by emergent social aggrandisers to support craft specialists and exchange for exotic valuables may have been a contributing factor.

With increasing aridity, emerging social hierarchy and greater specialisation prompted investment in water management, through moat and bank construction, to increase rice production at a time of greater ritual activity around rice symbolism. Graves from this period were filled with rice (Higham 2011), suggesting conspicuous consumption and the availability of surpluses. During Iron Age 4 at NBJ, the dead were interred in houses, accompanied by ritual offerings. Such residential burial is widely seen as a reflection of economic competition involving newly wealthy households (Adams \& King 2010). Therefore, we suggest that the move to wetland rice cultivation was predominantly driven by social demands for increased food surplus at a time of both increasing aridity and social competition. The possible presence of some subspecies indica rice in the Late Iron Age at (C) Antiquity Publications Ltd, 2018 


\section{Regional sequence}

A
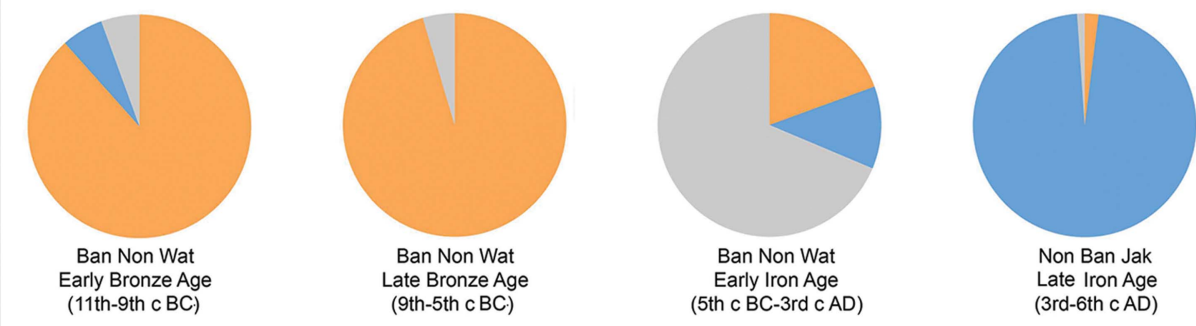

Figure 8. A) Charts from the regional sequences (BNW and NBJ), indicating the proportion of weeds in the archaeobotanical assemblages according to ecology, where 'indeterminate' includes weeds found in both dry and wet environments as well as those with no defined ecology; B) images of Diplacrum caricinum, a wetland weed, and Acmella paniculata, a dryland weed.

BNW suggests that the diversification of rice varieties probably also contributed to the increased resilience and productivity of rice overall.

It remains unclear whether wet rice cultivation was an entirely indigenous development or was influenced by cultural contacts. In the Ganges Plains of India, the expansion of rice agriculture occurred during the Iron Age and may have been linked to labour-intensive irrigated rice cultivation, population growth and urbanisation, especially from $c .800$ BC (Fuller \& Qin 2009). Elsewhere, such as in southern India, trade, craft specialisation and polity formation flourished alongside the adoption of less productive dry rice systems (Kingwell-Banham 2015), although the latter were part of a diversifying system of agriculture with a wide range of millets, pulses and cotton production (Cooke \& Fuller 2015). In peninsular and central Thailand, the links with India are well documented during the Late Metal Age (400 BC-AD 50) in the form of hard-stone artefacts, the use of Indian technologies in the production of ornaments, high-tin bronzes and crops such as mungbean, cotton and horsegram (Castillo \& Fuller 2010; Glover \& Bellina 2011; Bellina et al. 2014; Castillo et al. 2016a; Bellina 2017), although these sites lack evidence for wet rice or subspecies indica, which could have been brought in from India during this period but evidence suggests otherwise (Castillo et al. 2016a \& b).

In north-east Thailand where BNW is located, Indian influence is recognised through items of material culture, but is not as direct or profound as is seen in peninsula Thailand. The timing of the agricultural transition from the first century $\mathrm{BC}$ to the fourth century $\mathrm{AD}$ 
Cristina C. Castillo et al.
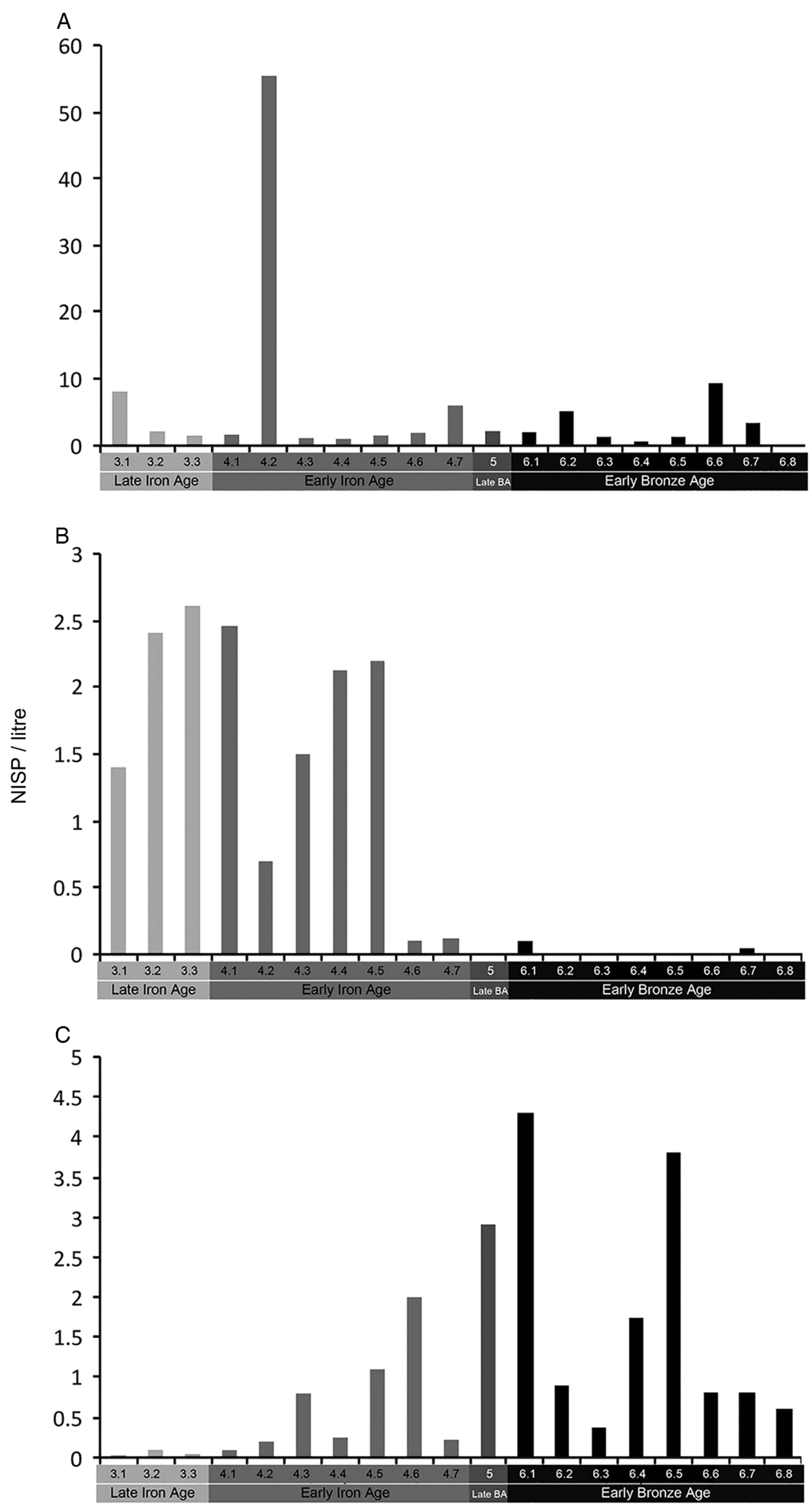

Samples BNW N96

Figure 9. NISP per litre of $A$ ) Oryza; $B$ ) Diplacrum caricinum; and C) Acmella paniculata.

(C) Antiquity Publications Ltd, 2018 
suggests that wetland rice agriculture at BNW and the Khorat Plateau in general developed independently of subsequent Indian influences. More archaeobotanical analyses documenting the ecology of rice cultivation, akin to that reported here, are needed from a broader geographic range of Southeast Asian sites in order to understand the emergence of wetland rice agriculture across the region.

\section{Concluding remarks}

From $100 \mathrm{BC}$, there was a progressive weakening of the monsoon in north-east Thailand that accelerated in the fourth century AD. This period is divided into four Iron Age phases (Figure 2). A series of behavioural changes have been identified within this time span alongside marked growth in population. During Iron Ages 3-4, banks were constructed to retain water in moats and reservoirs around the settlements. Remote sensing has identified canals and, in contemporaneous Iron Age sites in north-west Cambodia, bunded rice fields. It was during Iron Ages 3-4 that two new iron implements were forged: heavy socketed ploughshares and tanged sickles. At BNW, a layer comprising mixed water buffalo and cattle hoof prints suggests a corral for draught animals. This period also witnessed new mortuary rituals_-graves from Iron Age 3 were filled with rice. Some individuals were accompanied with a wealth of exotic ornaments including gold, silver, carnelian, agate, glass and bronze. By the time of Iron Age 4 at NBJ, some individuals were living in much larger houses in which the dead were sometimes also interred.

We have recovered a suite of plant remains from a sequence at BNW, dated rice grains and subjected the results to Bayesian modelling. Crucially, the weed seeds indicate dryland rice farming during the Bronze Age. This system relies on sufficient rainfall to bring rice to maturation. As the climate became drier during Iron Age 2, some aquatic weed species appeared. By the time of Iron Ages 3-4, the transition was complete, with virtually all weed seeds indicating wet rice cultivation. The social response to increasing aridity appears to have involved progressively more managed rice cultivation, seen in the provision of reservoirs linked to rice fields that were demarcated by bunds. These fields were prepared by ploughing, and harvesting was expedited by the use of iron sickles. It is, of course, possible that an egalitarian and cooperative community engineered this new system. We argue against this because some men and women were interred with such a high degree of mortuary wealth that they more probably represent social elites. One male at NUL was buried with a greater weight of bronze ornaments than those from all the Bronze Age burials across the region combined.

This 'agricultural revolution' had social repercussions. Rice has the potential to be much more than just a subsistence crop. Surpluses can be generated through the application of the plough and harrow in demarcated and improved fields. These fields are a measure of wealth that can be deployed by individuals for exchange, the provision of competitive feasts and for the projection of status through ritually impressive rites of passage. Such trends are reflected in the lavishly furnished graves that appear in the Late Iron Age sequence at NUL at precisely the same time as moat construction and the advent of wet rice cultivation.

These changes would have also brought with them serious implications for personal health. Reservoirs and other sources of permanently standing water attract both malarial mosquitoes and a wide range of molluscs and fish hosting pathogens. Thus, the Late Iron Age

(C) Antiquity Publications Ltd, 2018 
middens at NBJ contain thousands of shellfish probably collected from the surrounding wetlands. The species Indoplanorbis is just one of these. Of no dietary value, it is found in ponds and rice fields, and is the intermediate host that transmits the parasitic worms that cause bilharzia (Liu et al. 2010). Symptoms include diarrhoea, liver and kidney failure and bladder cancer. In Southeast Asia, it is particularly common among those accustomed to working in water that contains this snail, particularly rice farmers and fishermen. Bilharzia is second only to malaria in its impact on rural populations. It is unsurprising to find extremely high infant mortality and short adult life spans in societies that interred its dead with the iron sickles that would have been used by those wading through wet rice fields such as at NBJ. This agricultural revolution can thus be seen as favouring those who owned the best land and controlled organised labour, but not those who habitually worked in the rice fields.

That such social inequality arose in north-east Thailand is clearly documented in the texts inscribed from the sixth century AD. It is known that early states were raised and flourished on the basis of intensive rice cultivation in fields demarcated by fixed boundaries. There was increased distinction between the few members of elite lineages, and the considerable majority of rice-field workers. This foundation for state societies was further intensified during the six-century dominance of the kingdom of Angkor. It was during this period that rivers were diverted and channelled into massive reservoirs linked with a complex canal system to irrigate permanent rice fields. Labour-intensive and highly productive rice farming underpinned all historical states of Mainland Southeast Asia for the past 1000 years, as explored by Scott (2009). The contrast that he identifies between lowland rice states and upland, anarchic shifting cultivators only became possible in this part of Southeast Asia from the early centuries $\mathrm{AD}$ with the rise of wetland agriculture. While wetland rice-cultivation systems probably developed as adaptations to distinctly local conditions, we conclude that this agricultural innovation took place during the Iron Age and signified a turning point in the formation and durability of early Southeast Asian states.

\section{Acknowledgements}

We would like to thank the archaeological teams at BNW during the 2011 excavations; in particular, N96 pit supervisors Nathan Harris and Pimpicha Bannanurak. This research was supported by the Natural Environment Research Council Grant on 'The Impact of Intensification and Deintensification of Asian Rice Production: Transitions Between Wet and Dry Ecologies' (NE/N010957/1). Excavations were supported as follows: NUL and BNW 2001-2007 by the Marsden Fund of New Zealand and Earthwatch and its Research Corps; BNW 2011, including N96, by Earthwatch and its Research Corps; NBJ by the Marsden Fund, the University of Otago and by an Australian Research Council grant DP110101997 to D. O'Reilly and L. Shewan. BNW 2007-2011 excavations were co-directed by Amphan Kijngam, Warrachai Wiriyaromp, Kate Domett, William Boyd and Nigel Chang. We are grateful to the staff of the Oxford Radiocarbon Accelerator Unit for their careful laboratory work. BNW N96 samples were analysed by K. Miller as an MSc project with supervision from C. Castillo and D. Fuller (Miller 2014). BNW K500, BNW V200, NUL and NBJ were analysed by C. Castillo.

\section{Supplementary material}

To view supplementary material for this article, please visit https://doi.org/10.15184/aqy.2018.198

(C) Antiquity Publications Ltd, 2018 


\section{References}

Adams, R.L. \& S.M. KInG. 2010. Residential burial in global perspective, in R.L. Adams \& S.M. King (ed.) Residential burial: a multiregional exploration (Archaeological Papers of the American Anthropological Association 20): 1-160. Arlington (VA): American Anthropological Association.

Bellina, B. (ed.). 2017. Khao Sam Kaeo: an early port-city between the Indian Ocean and the South China Sea. Paris: École française d'ExtrêmeOrient.

Bellina, B., P. Silapanth, B. Chaisuwan, C. Thongcharoenchaikit, J. Allen, V. Bernard, B. Borell, P. Bouvet, C. Castillo, L. Dussubieux, J. Malakie, S. Srikanlaya, S. Peronnet \& T.O. Pryce. 2014. The development of coastal polities in the Upper Thai-Malay Peninsula, in N. Revire \& S.A. Murphy (ed.) Before Siam: essays in art and archaeology: 69-89. Bangkok: River.

BRAY, F. 1994. The rice economies: technology and development in Asian societies. Berkeley: University of California Press.

Brock, F., T.F.G. Higham, P. Ditchfield \& C.B. Bronk Ramsey. 2010. Current pretreatment methods for AMS radiocarbon dating at the Oxford Radiocarbon Accelerator Unit (ORAU). Radiocarbon 52: 103-12. https://doi.org/10.1017/S0033822200045069

Bronk Ramsey, C. 2009. Bayesian analysis of radiocarbon dates. Radiocarbon 51: 337-60. https://doi.org/10.1017/S0033822200033865

Buckley, B.M., K.J. Anchukaitis, D. Penny, R. Fletcher, E.R. CoOK, M. Sano, L.C. Nam, A. Wichienkeeo, T.T. Minh \& T.M. Hong. 2010. Climate as a contributing factor in the demise of Angkor, Cambodia. Proceedings of the National Academy of Sciences of the USA 107: 6748-52. https://doi.org/10.1073/pnas.0910827107

Castillo, C. 2011. Rice in Thailand: the archaeobotanical contribution. Rice 4(3-4): $114-20$. https://doi.org/10.1007/s12284-011-9070-2

- 2013. The archaeobotany of Khao Sam Kaeo and Phu Khao Thong: the agriculture of late prehistoric southern Thailand. Unpublished PhD dissertation, University College London.
- 2017. Development of cereal agriculture in prehistoric Mainland Southeast Asia. Man in India 97: 335-52.

Castillo, C. \& D.Q. Fuller. 2010. Still too fragmentary and dependent upon chance? Advances in the study of early Southeast Asian agriculture, in B. Bellina, J. Wisseman, E. Bacus \& T.O. Pryce (ed.) 50 years of archaeology in Southeast Asia: studies in honour of Ian Glover: 90-111. Bangkok: River.

Castillo, C., B. Bellina \& D.Q. Fuller. 2016a. Rice, beans and trade crops on the early maritime silk route in Southeast Asia. Antiquity 90: 1255-69. https://doi.org/10.15184/aqy.2016.175

Castillo, C.C., K. Tanaka, Y.-I. Sato, R. Ishikawa, B. Bellina, C. Higham, N. Chang, R. Mohanty, M. Kajale \& D.Q. Fuller. 2016 b. Archaeogenetic study of prehistoric rice remains from Thailand and India: evidence of early japonica in South and Southeast Asia. Archaeological and Anthropological Sciences 8: 523-43. https://doi.org/10.1007/s12520-015-0236-5

Castillo, C.C., D.Q. Fuller, P.J. Piper, P. Bellwood \& M. Oxenham. 2017. Huntergatherer specialization in the Late Neolithic of southern Vietnam-the case of Rach Nui. Quaternary International. http://dx.doi.org/10.1016/j.quaint.2016.11.034

Cooke, M. \& D.Q. Fuller. 2015. Agricultural continuity and change during the Megalithic and Early Historic periods in south India, in K.K. Basa, R. Mohanty \& S.B. Ota (ed.) Megalithic traditions in India. Archaeology and ethnography: 445-76. Delhi: Aryan Books International.

Dee, M. \& C.B. Bronk Ramsey. 2000. Refinement of graphite target production at ORAU. Nuclear Instruments and Methods in Physics Research Section B: Beam Interactions with Materials and Atoms 172: 449-53. https://doi.org/10.1016/S0168-583X(00) 00337-2

Fletcher, R., C. Рottier, D. Evans \& M. Kummu. 2008. The development of the water management system of Angkor: a provisional model. Bulletin of the Indo-Pacific Prehistory Association 28: 57-66.

FulLeR, D.Q. \& L. QIN. 2009. Water management and labour in the origins and dispersal of Asian rice. World Archaeology 41: 88-111. https://doi.org/10.1080/00438240802668321 
Fuller, D.Q., J.V. Etten, K. Manning, C. Castillo, E. Kingwell-Banham, A. Weisskopf, L. Qin, Y.-I. Sato \& R.J. Hijmans. 2011. The contribution of rice agriculture and livestock pastoralism to prehistoric methane levels: an archaeological assessment. The Holocene 21: 743-59. https://doi.org/10.1177/0959683611398052

Glover, I.C. \& B. Bellina. 2011. Ban Don Ta Phet and Khao Sam Kaeo: the earliest Indian contact reassessed, in P.-Y. Manguin, A. Mani \& G. Wade (ed.) Early interactions between South and Southeast Asia: reflections on cross-cultural movements: 17-45. Singapore: Institute of Southeast Asian Studies.

HaWKen, S. 2011. Metropolis of ricefields: a topographic classification of a dispersed urban complex. Unpublished PhD dissertation, University of Sydney.

Higham, C.F.W. 2011. The Iron Age of the Mun Valley, Thailand. The Antiquaries Journal 91: 1-44. https://doi.org/10.1017/S0003581511000114

- 2014. From the Iron Age to Angkor: new light on the origins of a state. Antiquity 88: 822-35. https://doi.org/10.1017/S0003598X00050717

Higham, C.F.W. \& T.F.G. Higham. 2009. A new chronological framework for prehistoric Southeast Asia, based on a Bayesian model from Ban Non Wat. Antiquity 82: 125-44. https://doi.org/10.1017/S0003598X00098136

Higham, C.F.W. \& A. Kijngam (ed.). 2012. The origins of the civilization of Angkor, volume VI. The Iron Age: summary and conclusions. Bangkok: Fine Arts Department of Thailand.

Higham, C.F.W. \& S. Tацвот (ed.). 2007. The origins of the civilization of Angkor, volume II. The excavation Noen U-Loke and Non Muang Kao. Bangkok: Fine Arts Department of Thailand.

Higham, C.F.W., J. Cameron, N. Chang, C.C. Castillo, D. O’Reilly, S.E. Halcrow, F. Petchey \& L. Shewan. 2014. The excavation of Non Ban Jak, northeast Thailand-a report on the first three seasons. Journal of Indo-Pacific Archaeology 34: 1-41. https://doi.org/10.7152/jipa.v34i0.14721

Higham, C.F.W., K. Douka \& T.F.G. Higham. 2015. A new chronology for the Bronze Age of northeastern Thailand and its implications for Southeast Asian prehistory. PloS One 10(9): e0137542.

https://doi.org/10.1371/journal.pone.0137542
Kingwell-Banham, E.J. 2015. Early rice agriculture in South Asia: identifying cultivation systems using archaeobotany. Unpublished $\mathrm{PhD}$ dissertation, University College London.

Liu, L., M.H. Mondal, M.A. IDRIs, H.S. LoKMan, P. Rajapakse, F. Satrija, J.L. Diaz, E.S. Upatham \& S.W. Attwood. 2010. The phylogeography of Indoplanorbis exustus (Gastropoda: Planorbidae) in Asia. Parasites \& Vectors 3(1): 57. https://doi.org/10.1186/1756-3305-3-57

Miller, K. 2014. Archaeobotanical remains from Ban Non Wat rice agriculture in prehistoric Thailand. Unpublished MSc dissertation, University College London.

Moody, K. 1989. Weeds reported in rice in South and Southeast Asia. Laguna: International Rice Research Institute.

O'ReILly, D.J.W. 2014. Increasing complexity and the political economy model; a consideration of Iron Age moated sites in Thailand. Journal of Anthropological Archaeology 35: 297-309. https://doi.org/10.1016/j.jaa.2014.06.007

Pandey, D.K., N. Mishra \& P. Singh. 2005. Relative phytotoxicity of hydroquinone on rice (Oryza sativa L.) and associated aquatic weed green musk chara (Chara zeylanica Willd.). Pesticide Biochemistry and Physiology 83: 82-96. https://doi.org/10.1016/j.pestbp.2005.03.013

Piepho, H.P. 1993. Weed species in irrigated ricefields in northeast Thailand. International Rice Research Notes 18(1): 52-53.

Raja, P., S. Soosairaj, N. Dhatchanamoorthy \& J.K. TAGORE. 2015. Floristic composition of aquatic angiosperms in different wetlands of Pudukkottai district of Tamil Nadu, India. Asian Journal of Plant Science and Research 5(12): 6-12.

Reimer, P.J., E. Bard, A. Bayliss, J.W. Beck, P.G. Blackwell, C. Bronk Ramsey, C.E. Buck, H. Cheng, R.L. Edwards, M. Friedrich, P.M. Grootes, T.P. Guilderson, H. Haflidason, I. Hajdas, C. Hatté, T.J. Heaton, D.L. Hoffmann, A.G. Hogg, K.A. Hughen, K.F. Kaiser, B. Kromer, S.W. Manning, M. Niu, R.W. Reimer, D.A. Richards, E.M. Scott, J. R. Southon, R.A. StafF, C.S.M. Turney \& J. VAN DER PLicht. 2013. IntCal13 and Marine13 radiocarbon age calibration curves $0-50,000$ years cal BP. Radiocarbon 55: 1869-87. https://doi.org/10.2458/azu_js_rc.55.16947

(C) Antiquity Publications Ltd, 2018 
Scott, G. \& D. O’Reilly. 2015. Rainfall and circular moated sites in north-east Thailand. Antiquity 89: 1125-38. https://doi.org/10.15184/aqy.2015.130

Sсотт, J.C. 2009. The art of not being governed: an anarchist history of upland Southeast Asia. New Haven (CT): Yale University Press.

Simpson, D.A. \& C.A. Inglis. 2001. Cyperaceae of economic, ethnobotanical and horticultural importance: a checklist. Kew Bulletin 56: 257-360. https://doi.org/10.2307/4110962

Smitinand, T. 1986. Weeds in shifting cultivation in Thailand, in K. Noda \& B.L. Mercado (ed.) Weeds and the environment in the tropics (Proceedings of the Symposium of the Tenth Conference of the Asian Pacific Weed Science Society): 79-99. Bangkok: Asian-Pacific Weed Science Society and Japan International Cooperation Agency.

Stargardt, J. 1986. Hydraulic works and Southeast Asia polities, in D.G. Marr \& A.C. Milner (ed.) Southeast Asia in the $9^{\text {th }}$ and $14^{\text {th }}$ centuries: 23-49. Singapore: Institute of Southeast Asian Studies.
Sullivan, A.P. 1987. Seeds of discontent: implications of a 'pompeii' archaeobotanical assemblage for Grand Canyon Anasazi subsistence models. Journal of Ethnobiology 7 : 137-53.

Weber, S., H. Lehman, T. Barela, S. Hawks \& D. HARRIMAN. 2010. Rice or millets: early farming strategies in prehistoric central Thailand. Archaeological and Anthropological Sciences 2(2): 79-88. https://doi.org/10.1007/s12520-010-0030-3

Weisskopf, A., L. Qin, J. Ding, P. Ding, G. Sun \& D. Fuller. 2015. Phytoliths and rice: from wet to dry and back again in the Neolithic Lower Yangtze. Antiquity 89: 1051-63. https://doi.org/10.15184/aqy.2015.94

Wohlfarth, B., C.F.W. Higham, K.A. Yamoah, A. Chabangborn, S. Chawchai \& R.H. Smittenberg. 2016. Human adaptation to mid to Late Holocene climate change in northeast Thailand. The Holocene 26: 614-26. https://doi.org/10.1177/0959683616645947

Received: 20 July 2017; Revised: 2 December 2017; Accepted: 4 January 2018 